ATTHULAB:

Islamic Religion Teaching \& Learning Journal

Volume 5 Nomor 1 Tahun 2020

http://journal.uinsgd.ac.id./index.php/atthulab/

\title{
Curriculum Analysis of Persis 110 Bandung in the Curriculum Perspective Curriculum Reconstruction Social
}

\author{
Kahpiana ${ }^{1)}$ dan Rusman ${ }^{2}$ \\ Prodi Pengembangan Kurikulum Sekolah Pascasarjana \\ Universitas Pendidikan Indonesia \\ Jl. Dr. Setiabudi No.229, Isola, Kec. Sukasari, Kota Bandung, Jawa Barat, Indonesia \\ 1)Email: kahpiana@student.upi.edu \\ 2)Email: rusman@upi.edu
}

\begin{abstract}
This study aims: 1) to provide a description of curriculum planning, 2) the implementation of the pesantren curriculum, 3) the evaluation of the pesantren curriculum, in the perspective of the social reconstruction curriculum. This research was conducted because the PPI curriculum number 110 has the characteristic of translating the implementation of learning consciously to form a critical person and be able to make students as pioneers in social sustainability in the pesantren environment and beyond. This research method is descriptive qualitative. The research design involved the triagulation method with interviews with the dipesantren steakholders, the madrasah head, deputy head of the curriculum, madrasa aliyah teachers, study of curriculum documentation, and observations of learning at the pesantren. The results of the study, curriculum planning in the pesantren in the perspective of social reconstruction have not included planning criteria in view of social reconstruction, curriculum implementation in the pesantren in the perspective of social reconstruction there is a revival between teachers and students / students in an equal communication process, evaluation of the curriculum in the pesantren in social reconstruction perspective, there is an integrated homework strategy pattern as part of a continuous and objective assessment pattern, evaluation aims to create a qualitative value that is honesty, the implications of this research for the process of treasuring the social reconstruction curriculum.
\end{abstract}

Keywords:

Curriculum; Pesantren; Social Reconstruction

\begin{abstract}
Abstrak: Tujuan umum penelitian ini adalah 1) untuk memberikan deskripsi tentang perencanaan kurikulum, 2) implementasi kuriukulm pesantren, 3) evaluasi kurikulum pesantren, dalam cara pandang kurikulum rekonstreuksi sosial. Penelitian ini dilakukan karena kurikulum PPI Nomor 110 memilki ciri khas menerjemahkan implementasi pembelajaran secara sadar membentuk pribadi yang kritis serta mampu menjadikan santri sebagi pionir dalam keberlangsungan sosial di lingkungan pesantren dan diluar. Metode penelitian ini adalah deskriptif kualitatif. Desain penelitian melibatkan metode triagulasi dengan metode wawancara dengan stakeholder dipesantren tersebut, kepala madrasah, wakil kepala bagian kurikulum, guru madrasah aliyah, studi dokumentasi kurikulum, dan observasi pembelajaran di pesantren tersebut. Hasil penelitian, perencanaan kurikulum di pesantren tersebut dalam perspektif rekonstruksi sosial belum mencangkup kriteria perencanaan dalam pandangan rekonstruksi sosial, implementasi kurikulum di pesantren tersebut dalam perspektif rekonstruksi sosial adanya keterbangunan antara guru dan siswa / santri dalam proses komunikasi yang setara, evaluasi kurikulum di pesantren tersebut dalam perspektif rekonstruksi sosial, ada pola integrateg homework sebagai bagian dari pola penilaian secara terus menerus dan dilakukan secara objektif, evaluasi bertujuan untuk terciptannya nilai kualitatif yakni kejujuran, implikasi penelitian ini untuk proses khazanah tentang kurikulum rekonstruksi sosial.
\end{abstract}

Kata Kunci:

Kurikulum; Pesantren; Rekonstruksi Sosial

DOI: http://dx.doi.org/10.15575/ath.v5i1.7619 


\section{PENDAHULUAN}

Received: 02, 2020. Accepted: 04, 2020. Published: 04, 2020.

Motivasi setiap orang tua dalam menyekolahkan anaknya kepada pondok pesantren berbeda-beda. Beberapa orang tua menginginkan supaya anak paham tentang ajaran agama, ada yang menginginkan supaya anak menjadi sholeh dan sholehah, dan ada juga yang menginginkan anaknya menjadi penghafal Al-Quran dan juga karena di pondok pesantren mempunyai kegiatan yang positif setiap harinya dan selalu dibimbing dan diarahkan pada pendidikan yang lebih baik.

Transformasi lembaga pendidikan pondok pesantren dari lembaga pendidikan yang dainggap 'tradisional' sekarang berubah menjadi sebuah sistem pendidikan Islam seperti yang kita lihat sekarang ini, lama kelamaan akan menyesuaikan diri kedalam sistem pendidikan umum. (Steenbrink, 1991, p. 7)

Perubahan dalam bidang pendidikan telah terjadi secara drastis pada akhir abad dua puluh. Dari berbagai faktor yang mempengaruhinya, tidak ada yang lebih mendasar dibandingkan dengan perubahan yang terjadi dalam kurikulum (Kelly :1977). Sifatnya yang sangat mendasar ditujukan oleh fakta bahwa kurikulum merupakan landasan utama dari setiap sistem pendidikan. Perubahan dalam kurikulum telah berpengaruh secara langsung terhadap pemerataan pendidikan, relevansi pendidikan dan sumber-sumber pembelajaran.

Model pondok pesantren sebagai berikut ; 1) Pondok pesantren secara tradisional; 2) Pondok pesantren secara klasikal (madrasi); 3) Pondok pesantren yang hanya merupakan asrama sedangkan santrinya belajar di luar; dan 4) Pondok pesantren yang menyelenggarakan sistem pondok pesantren dan sekaligus sistem sekolah atau madrasah. (Wahid, 2001, p. 15) Sedangkan, klasifikasi pondok pesantren paling tidak bisa dibagi menjadi dua ; Pertama, dari segi baguanan fisik dan sarana pra-sarana, Kedua, dari segi kurikulum. (Endin, 2005, p. 22)

Maka seyogyanya pendidikan pesantren harus mempunyai konsep kurikulum rekontruksi sosial, dimana kurikulum ini lebih memusatkan perhatian pada problem-problema yang dihadapinya dalam masyarakat. Kurikulum ini bersumber pada aliran pendidikan interaksional. Agar kurikulum di pesantren relevan dengan kondisi masyarakat serta menyiapkan siswa-siswa yang siap guna.

Oleh karena itu rumusan dalam jurnal ini terhadap analisis kurikulum di PPI No. 110 Manba'ul Huda penelitian yang mencangkup tiga hal (1) Perencanaan kurikulum Pesantren (2) Implementasi Kurikulum (3) Evaluasi Kurikulum dari ketiganya itu dipandang dari perspektif kurikulum rekonstruksi sosial. 
Curriculum analysis of Persis 110 Bandung in the curriculum perspective curriculum reconstruction social

Pesantren atau pondok pesantren, menurut istilah adalah suatu lembaga pendidikan tradisional Islam untuk mempelajari, memahami, mendalami, menghayati, dan mengamalkan ajaran Islam dengan menekankan pentingnya moral keagamaan sebagai pedoman perilaku sehari-hari. (Mastuhu, 1994, p. 55)

Pemerintah melalui Undang-Undang Sistem Pendidikan Nasional Nomor 20 Tahun 2003 pasal 30 ayat 4 menyebutkan bahwa Pendidikan keagamaan berbentuk pendidikan diniyyah, pesantren, pasraman, pabhaja, samanera dan bentuk lain yang sejenis. Dalam ayat tersebut pesantren digolongkan pada pendidikan keagamaan. Untuk memperjelas ayat di atas, pemerintah melalui Peraturan Pemerintah Nomor 55 Tahun 2007 tentang Pendidikan Agama dan Keagamaan, dalam pasal 1 ayat 4 dijelaskan bahwa pesantren atau Pondok Pesantren adalah lembaga pendidikan keagamaan Islam berbasis masyarakat yang menyelanggara-kan pendidikan diniyyah atau secara terpadu dengan jenis pendidikan lainnya. (Depdiknas, 2003)

Kurikulum secara etimologi berasal dari bahasa Yunani "curir", yang artinya pelari dan "curere" yang artinya tempat berpacu. kurikulum berasal dari dunia olahraga, terutama dalam bidang atletik pada zaman Romawi Kuno di Yunani. Pada saat itu arti kurikulum ialah jangka waktu pendidikan yang harus dilalui oleh peserta didik yang bertujuan untuk mendapatkan ijazah. (Arifin, 2012, p. 2)

Kurikulum menurut Undang-undang Nomor 20 Tahun 2003 berisikan tentang Sistem Pendidikan Nasional, Kurikulum adalah seperangkat rencana dan pengaturan mengenai tujuan, isi, dan bahan pelajaran, serta cara yang digunakan sebagai pedoman penyelenggaraan kegiatan pembelajaran untuk mencapai tujuan pendidikan tertentu. (Depdiknas, 2003)

Kurikulum secara terminologi dalam pandangan ahli Robert S. Zais yang menyatakan bahwa "...curriculum is a racecourse of subject matters to be mastered" dari pernyataan Zais dijelaskan bahwa kurikulum adalah sebuah rangkaian mata pelajaran yang harus dikuasai. Kurikulum merupakan mata palajaran yang harus dipahami, dikuasai, dipelajari dan diketahui oleh seorang guru dalam mendidik seorang murid, sehingga apa yang ia berikan kepada muridnya merupakan hal yang sudah ia kuasai secara detail mengenai mata pelajaran yang akan di berikan kepada murid. (Zais, 1976, p. 7)

Sejalan dengan Beauchamp yang menyatakan bahwa "A curriculum is a written document which may contain many ingredients, but basically it is a plan for the education of pupils during their enrollment in given school." Beauchamp menjelaskan bahwa kurikulum adalah dokumen tertulis yang terdiri kontenkonten materi, namun pada dasarnya adalah rencana untuk pendidikan 
murid selama mereka melakukan kegiatan dipersekolahan. Beauchamp ini menitikberatkan pada rencana atau planning seorang guru. (Beauchamp, 1975, p. 7)

Hal-hal yang perlu di perhatikan juga dalam kurikulum harus memiliki perencanaan kurikulum yang diantaranya :

a. Perumusan tujuan kurikulum

b. Landasan Perencanaan Kurikulum

c. Perumusan Isi Kurikulum

d. Model Perencanaan Kurikulum. (Rusman, 2009, pp. 25-26)

Menurut Hasan (1998) ada beberapa faktor yang mempengaruhi implementasi kurikulum, karekteristik kurikulum, strategi implementasi, karekteristik penilaian, pengetahuan guru tentang kurikulum, sikap terhadap kurikulum, dan keterampilan mengarahkan.

Sementara itu, menurut Mars terdapat lima elemen yang mempengaruhi implementasi kurikulum sebagai berikut: dukungan dari kepala sekolah, dukungan dari sejawat guru, dukungan dari siswa, dukungan dari orang tua, dan dukungan dari diri dalam guru unsur yang utama yaitu :

a. Kemampuan guru dalam mengimplementasikan kurikulum

b. Kendala yang dihadapi guru dalam mengimplementasikan kurikulum

c. Model - model implementasi kurikulum. (Rusman, 2009, p. 74)

Evaluasi menurut Grounlund adalah suatu proses yang sitematis dari pengumpulan, analisis dan intrepretasi informasi/data untuk menentukan sejauh mana siswa telah mencapai tujuan pembelajaran. (Rusman, 2009, p. 93)

a. Tujuan Evaluasi Kurikulum

Seperti yang dinyatakan oleh scriven (1967), evaluasi sumatif menfokuskan pada hasil program secara keseluruhan, ini bisa berasal dari sekolah atau sistem sekolah atau sumber di luar sekolah. (Rusman, 2009, p. 95)

b. Model - model Evaluasi

Pendapat lain memberi ulasan bahwa model evaluasi diantaranya: evaluasi kebutuhan dan feasibility, evaluasi masukan (input), evaluasi proses, dan evaluasi product. (Hamalik, Oemar, 2007, pp. 258259)

Maka dalam jurnal ini akan membahas tentang pesantren yang menggunakan kurikulum rekonstruksi sosial, sedangkan kurikulum rekonstruksi sosial sendiri berbeda dengan model-model kurikulum lainnya. Kurikulum ini lebih memusatkan perhatian pada problem-problema yang dihadapinya dalam masyarakat. Kurikulum ini bersumber pada aliran pendidikan interaksional. Menurut mereka pendidikan bukan upaya sendiri, 
Curriculum analysis of Persis 110 Bandung in the curriculum perspective curriculum reconstruction social

melainkan kegiatan bersama, interaksi dan kerja sama. Kerja sama atau interaksi bukan hanya terjadi antara siswa dengan guru, tetapi juga antara siswa dengan siswa, siswa dengan orang-orang di lingkungannya, dan dengan sumber belajar lainnya. Melalui interaksi dan kerja sama ini siswa berusaha memecahkan problema-problema yang dihadapinya dalam masyarakat menuju pembentukan masyarakat yang lebih baik. (Sukmadinata, 2014, p. 96)

Para rekonstruksionis sosial tidak mau terlalu menekankan kebebasan individu. Mereka ingin menyakinkan murid-murid bagaimana masyarakat membuat warganya seperti yang ada sekarang dan bagaimana masyarakat memenuhi kebutuhan pribadi warganya melalui konsensus sosial. Brameld juga ingin memberikan keyakinan tentang pentingnya perubahan sosial. Perubahan sosial tersebut harus dicapai melalui prosedur demokrasi. Para rekonstruksionis sosial menentang intimidasi, menakut-nakuti dan kompromi semu. Mereka mendorong agar para siswa mempunyai pengetahuan yang cukup tentang masalah-masalah sosial yang mendesak (crucial) dan kerja sama atau bergotong-royong untuk memecahkannya.

a. Ciri-ciri Kurikulum Rekonstruksi Sosial.

Ada beberapa ciri-ciri desain kurikulum rekonstruksi sosial antara lain:

1) Asumsi. Tujuan utama kurikulum rekonstruksi social adalah menghadapkan para siswa pada tantangan, ancaman, hambatanhambatan atau gangguan-gangguan yang dihadapi manusia. Tantangan-tantangan tersebut merupakan bidang garapan studi social, yang perlu didekati dari bidang lain seperti ekonomi, sosiologi, psikologi, estetika, bahkan pengetahuan alam dan matematika. Masalah-masalah masyarakat bersifat universal dan hal ini dapat dikaji dalam kurikulum.

2) Masalah-masalah social yang mendesak. Kegiatan social dipusatkan pada masalah-masalah social yang mendesak. Masalah-masalah tersebut dirumuskan dalam pertanyaan, seperti: Dapatkah kehidupan seperti sekarang ini member kekuatan untuk menghadapi ancaman-ancaman yang akan mengganggu integritas kemanusiaan? Dapatkah tata ekonomi dan politik yang ada dibangun kembali agar setiap orang dapat memanfaatkan sumbersumber daya alamdan sumber daya manusia seadil mungkin. Pertanyaan-pertanyyan tersebut mengundang pengungkapan lebih mendalam, bukan saja dari buku-buku dan kegiatan laboratorium tetapi juga dari kehidupan nyata dalam masyarakat.

3) Pola-pola organisasi. Pada tingkat sekolah menegah, pola organisasi kurikulum disusun seperti sebuah roda. Ditengah-tengahnya sebagai poros dipilih sesuatu masalah yang menjadi tema utama dan dibahas secara pleno. Dari tema utama dijabarkan sejumlah topik 
yang dibahas dalam diskusi-diskusi kelompok, latihan-latihan, kunjungan dan lain-lain. Topic-topik dengan berbagai kegiatan kelompok ini merupakan jari-jari. Semua kegiatan jari-jari tersebut dirangkum menjadi satu kesatuan sebagai bingkai atau velk. (Arifin, 2012, p. 130)

b. Komponen - komponen kurikulum rekonstruksi sosial

Kurikulum rekonstruksi sosial memilki komponen-komponen yang sama dengan model kurikulum lain tetapi isi dan bentuk-bentuknya berbeda.

1) Tujuan Kurikulum

Kegiatan yang dilakukan untuk mencapai tujuan tersebut adalah antara lain:

a) mengadakan survei secara kritis terhadap masyarakat

b) mengadakan studi tentang hubungan antara keadaan ekonomi lokal dan ekonomi nasional serta dunia

c) mengadakan studi tentang latar belakang historis dan kecenderungan-kecenderungan perkembangan ekonomi, hubungannya dengan ekonomi lokal

d) mengkaji praktik politik dalam hubungannya dengna faktor ekonomi.

e) memantapkan rencana perubahan praktik politik.

f) mengevaluasi semua rencana dengan kriteria, apakah telah memenuhi kepentingan sebagian besar orang. (Hamalik, 2008, p. 146)

2) Metode Kurikulum rekonstruksi sosial

Dalam pengajaran rekonstruksi sosial para pengembang kurikulum berusaha mencari keselarasan antara tujuan-tujuan nasional dengan tujuan siswa. Guru-guru berusaha membantu para siswa menemukan minat dan kebutuhannya. Sesuai dengan minat masing-masing siswa, baik dalam kegitan pleno maupun kelompok-kelompok berusaha memecahkan masalah sosial yang dihadapinya. Kerja sama baik antara individu dalam kegiatan kelompok, maupun antar kelompok dalam kegiatan pleno sangat mewarnai metode rekonstrusi sosial. Kerja sama ini juga terjadi antara para siswa dengan manusia sumber dari masyarakat. Bagi rekonstruksi sosial, belajar merupakan kegiatan bersama, ada ketergantungan antara seorang dengan yang lainnya.

3) Implementasi Kurikulum rekonstruksi sosial

Guru dan siswa belajar bersama, guru membantu siswa menemukan minat/kebutuhannya dan bersama siswa memecahkan masalah sosial yang dihadapi. Dalam kegiatan belajar tidak ada kompetisi, yang ada adalah kooperasi atau kerjasama, kerja kelompok, saling pengertian, dan konsensus 
Curriculum analysis of Persis 110 Bandung in the curriculum perspective curriculum reconstruction social

Pengajaran rekontruksi sosial banyak dilaksanakan di daerahdaerah yang tergolong belum maju dan tingkat ekonominya belum tinggi. Pelaksanaan pengajaran ini diarahkan untuk meningkatkan kondisi kehidupan masyarakat. Sesuai dengan potensi yang ada di dalam masyarakat, sekolah mempelajari potensi-potensi tersebut, dengan bantuan biaya dari pemerintah

4) Evaluasi Kurikulum rekonstruksi sosial

Dalam kegiatan evaluasi para siswa juga dilibatkan, keterlibatan mereka terutama dalam memilih, menyusun, dan menilai bahan yang akan diujikan. Soal-soal yang akan diujikan dinilai lebih dulu baik ketepatan maupun keluasan isinya, juga keampuhan menilai pencapaian tujuan-tujuan pembangunan masyarakat yang sifatnya kualitatif. Evaluasi tidak hanya menilai apa yang telah dikuasai siswa, tetapi juga menilai pengaruh kegiatan sekolah terhadap masyarakat. Pengaruh tersebut terutama menyangkut perkembangan masyarakat dan peningkatan taraf kehidupan masyarakat.

5) Pembelajaran Kurikulum Rekonstruksi Sosial

Pengajaran rekontruksi sosial banyak dilaksanakan di daerahdaerah yang tergolong belum maju dan tingkat ekonominya juga belum tinggi. Pelaksanaan pengajaran ini diarahkan untuk meningkatkan kondisi kehidupan mereka. Sesuai dengan potensi yang ada dalam masyarakat, sekolah mempelajari potensi-potensi tersebut, dengan bantuan biaya dari pemerintah sekolah berusaha mengembangkan potensi tersebut. Didaerah pertanian umpamanya sekolah mengembangkan bidang pertanian dan peternakan, didaerah industri mengembangkan bidang-bidang industri.

Paulo Freire sebagai seorang anggota Dinas Pendidikan Sao Paulo, Brazil dan sekaligus aktifis partai kiri mempunyai pandangan sendiri dalam bidang pendidikan. Bahwasannya dia membagi kesadaran dalam tiga tahap, kesadaran tersebut adalah bagian dari masyarakat pada masa itu yang mempunyai pengaruh penting dalam kehidupan. Kesadaran tersebut adalah kesadaran magis, kesadaran naif, dan kesadaran kritis.

Sekolah berusaha memberikan penerangan dan melatih kemampuan untuk melihat dan mengatasi hambatan-hambatan yang dihadapi. Dengan gerakan Contscientization mereka membantu masyarakat memahami fakta-fakta dan masalahmasalah yang dihadapi dalam konteks kondisi masyarakat mereka. 
Pandangan rekonstruksi sosial berkembang karena keyakinannya pada kemampuan manusia untuk membangun dunia yang lebih baik, juga penekannya tentang peranan ilmu dalam memecahkan masalah-masalah sosial.

\section{METODE PENELITIAN}

Pendekatan dalam penelitian ini menggunakan grounded theory designs yaitu prosedur kualitatif yang sistematis yang digunakan peneliti untuk memunculkan penjelasan umum (gorunded) berasaskan pandangan partisipan yang disebut gorunded theory, yang menjelaskan proses, tindakan, atau interaksi di antara para partisipan. Prosedur untuk mengembangkan teori ini termasuk mengumpulkan data wawancara, mengembangkan dan mengaitkan kategori atau tema informasi, dan menyusun gambar atau model visual yang memotert penjelasan umumnya. Dengan cara ini, penjelasan didasarkan data dari partisipan. Dari penjelasan ini, kita mengontruksikan pernyataan prediktif tentang pengalaman individu. (Creswell, 2015, p. 42)

Untuk langkah - langkah dalam penelitian ini dijelaskan sebagai berikut :

a. Wawancara mendalam

Teknik ini digunakan untuk pengumpulan data pada penelitian ini dikarenakan melalui wawancara mendalam, kemampuan intelektual, sebagai bagian dari konsep strategi, yang berupa pemikiran, gagasan, serta wawasan seseorang akan terungkap sebagaimana dinyatakan oleh selain itu, kita dapat memasuki dunia pikiran dan perasaan para responden.

Wawancara dilakukan dengan berdialog dan tanya jawab dengan kepala sekolah, dan juga guru yang bertugas serta para santri secara langsung di Pesantren Persis Nomor 110 Bandung. Hasil-hasil wawancara kemudian dituangkan dalam struktur ringkasan, yang dimulai dari penjelasan ringkas identitas, deskripsi situasi oatau konteks, identitas masalah, deskripsi data, unitisasi dan ditutup dengan pemunculan tema.

b. Studi Dokumentasi

Penulis mempelajari dokumentasi kurikulum merupakan hal yang sangat penting dalam sebuah penelitian karena data-data yang didapat dari hasil observasi harus berbentuk nyata dalam sebuah gambar atau dokumentasi, dokumentasi yang digunakan adalah dokumentasi kurikulum Mandrasah Aliyah tahun ajaran 2019/2020 Pesantren 
Curriculum analysis of Persis 110 Bandung in the curriculum perspective curriculum reconstruction social

Pesantuan Islam No. 110 Bandung Hasil dokumentasi inilah yang dapat dijadikan bukti dilaksanakannya proses penelitian.

c. Tinjauan Literatur

Peneliti membaca buku - buku yang dapat membantu peneliti melakukan penelitian untuk memperoleh data yang relevan. Tinjauan literatur digunakan sebagai bagian dari komponen teknik pengumpulan data. pemahaman tentang tinjauan literatur adalah sebagai berikut pada tinjauan literatur, seseorang secara sistematis memcoba membaca semua literatur yang relevan dalam sebuah subjek, kadang - kadang mewawancarai pakar dalam subjek tersebut, kemudian mengorganisasi, mensistesis dan menilai secara kritis sejumlah julatan informasi.

\section{HASIL PENELITIAN DAN PEMBAHASAN}

Pesantren Persatuan Islam (PPI) Nomor 110 Manba'ul Huda Bandung merupakan pondok pesantren yang berada di bawah naungan Persatuan Islam (PERSIS). Model Penyelenggaraannya sistem pondok pesantren dan sekaligus sistem sekolah atau madrasah, melayani pendidikan dimulai dari Madrasah Ibtidaiyah Diniyah, Madrasah Tsanawiyah, Madrasah Aliyah. Klasifikasi dalam segi bangunan fisik sudah ada sarana masjid, rumah kyai, pondok, madrasah tempat keterampilan, gedung pertemuan, tempat olah raga, dan sekolah umum. Pesantren yang sudah berkembang dan bisa digolongkan pesantren mandiri. Pesantren seperti ini telah memilki perpustakaan, dapur umum, ruang makan, kantor administrasi, toko, rumah penginapan tamu, ruang operation room, dan sebagainya disamping itu pesantren ini mengelola sekolah tingkat dasar ${ }^{1}$.

a. Perencanaan Kurikulum pesantren dalam perspektif kurikulum rekonstruksi sosial

Dalam perencanaan kurikulum rumusan tujuan kurikulum pesantren bertujuan membentuk sifat Nubuwah (Shidiq, Amanah, Tabligh dan Fathonah) sebagai kerangka acuan rumusan tujuan, landasan rumusan kurikulum pesantren ini adalah Qur'an dan Sunah, rumusan tujuan kemudian dijabarkan dalam muatan perencanaan isi kurikulum pesantren ini, model prencanaan kurikulum menggunakan model non perencanaan kurikulum artinya semua kurikuum yang sudah disarankan oleh pemerintah kita jalankan dan kurikulum yang diberikan oleh Persis kita jalankan, akan tetapi hal landasan kita perubahan

1 Hasil observasi yang dilakukan oleh peneliti pada tanggal 28 Nopember 2019 
masyarakat yang kita ikuti sebagai dasar asumsi kita melaksanakan kurikulum².

Model non-planing Adalah suatu model berdasarkan pertimbangan - pertimbangan intuitif guru - guru di dalam ruangan kelas sebagai bentuk pembuatan - pembuatan keputusan, hanya sedikit upaya kecuali perumusan tujuan khusus, formalitas pendapat, dan analis intelektual.

Dalam perspektif kurikulum rekonstruksi sosial perencanaan kurikulum Shane menggunakan perencanaan masa yang akan datang (Futurologist) sebagai dasar penyusunan kurikulum. Beliau menekankan peranan individu dalam menemukan peranan masa depanya sendiri, mereka tidak dapat melepaskan diri dari perkembangannya akan tetapi harus menyesuaikannya. Shane menyarankan para pengembang kurikulum agar mempelajari tren perkembangan. Tren utama adalah perkembangan teknologi dengan berbagai dampaknya terhadap kondisi dan perkembangan masyarakat. Kecenderungan lain adalah perkembangan ekonomi , politik, sosial, dan budaya. (Hamalik, Oemar, 2007, p. 153)

b. Implementasi kurikulum dalam perspektif kurikulum rekonstruksi sosial

Secara historis pesantren manba'ul huda didirikan untuk menghidmat kepada msyarakat, yaitu pendidikan Islam bagi masyarakat dilingkungannya, hadirnya pesantren ini adalah untuk proses pelayanan pendidikan bagi masyarakat perkotaan yang nota bene haus akan ilmu Islam, implementasi kurikulum yang dijalankan menggunakan dua model kurikulum yaitu kurikulum nasional dan kurikulum Persatuan Islam (Persis). Kitab klasik kita berikan kepada santri sebagai bekal mengenai makna Islam yang sesungguhnya, pembelajaran umum kita sampaikan untuk bekal hidupnya di dunia.

Dalam pengembangan kebijakanpun Namun dalam pelaksanaannya lebih husus di dalam kelas para asatidz (Guru) sebisa mungkin menggunakan metode praktis sehingga terbentuk pola kolmunikasi yang setara, sebagaimana yang di instruksikan oleh kepala Madrasah, Equal in Class. Tidak bisa kemudian seorang asatidz mendominasi ruang pembelajarannamun juga ada batasan tertentu yang digunakan untuk mencapai komunikasi yang efektif dalam pembelajaran ${ }^{3}$.

2 Hasil wawancara dengan kepala madrasah aliyah Manba'ul Huda Bandung Ustadz Rosihon Fahmi, M.Hum pada tanggal 29 Nopember 2019

${ }^{3}$ Wawancara dengan ustadz Huzaeni Ridwan, M.Pd pada tanggal 2019 
Curriculum analysis of Persis 110 Bandung in the curriculum perspective curriculum reconstruction social

Dalam pandangan teori kritis dalam pendidikan bahwa komunikasi dalam pembelajaran/pendidikan dilakukan secara setara seperti yang disampaikan oleh Jurgen Habermas memandang kegagalan tersebut disebabkan oleh pengertian praxis yang dianut oleh pendahulunya. Para pendahulunya hanya melihat praksis dalam arti tunggal yaitu kerja dan melupakan dimensi lain dari praksis yaitu komunikasi. Untuk mengerti pernyataan tersebut, kita harus mulai dengan konsep manusia yang dianut oleh Habermas. Manusia itu makhluk alam dan makhluk sosial. Dengan demikian, manusia itu hidup dalam dominasi dua kekuatan sekaligus yaitu kekuatan alam dan sosial. Untuk membebaskan diri dari dominasi alam, manusia melakukan kerja, yakni kegiatan mengubah alam menjadi budaya, mengubah alam untuk kepentingan hidup manusia. Ketika manusia melakukan kerja manusia sesungguhnya menaklukan alam di bawah kekuasannya. (Hardiman, 2009, pp. 143-144)

Dalam impelentasi kurikulum kita bisa mneggunakan pola komunikasi Jurgen Habermas, teori praxis sosial itu harus dilakukan lewat komunikasi atau bersifat komunikatif. Tujuan dari komunikasi ini menurut Habermas adalah untuk menciptakan suatu konsensus/kesepakatan yang bebas dari dominasi dan paksaan.

Bagaimana mencapai itu? Pertama bahwa perlu ada ruang publik (public sphere), sebuah ruang di mana pertukaran gagasan antara semua orang berlangsung. Sebuah ruang yang lagi-lagi juga harus bersih dari bentuk-bentuk dominasi dan paksaan. Semua yang hadir di dalam ruang tersebut adalah partisipan yang berkedudukan setara. Selain itu, komunikasi di ruang publik ini harus dilakukan dengan suatu kompetensi yang Habermas sendiri menyebutnnya dengan komptensi komunikasi. Kompetensi tersebut terdiri atas 4 macam, yaitu kebenaran, kejujuran, dan kompherensif dan gabungan dari ketiga-tiganya.

Model implementasi kurikulum di pesantren ini dalam analisis penulis menggunakan The Concerns-Based Adaption Model (CBAM) Model CBAM ini adalah sebuah model deskriptif yang dikembangkan melalui pengidentifikasian tingkat kepedulian guru terhadap sebuah inovasi kurikulum. Perubahan dalam inovasi ini ada dua dimensi, yakni tingkatan-tingkatan kepedulian terhadap inovasi. Perubahan yang terjadi merupakan suatu proses bukan peristiwa yang terjadi ketiga program baru diberikan kepada guru, merupakan pengalaman pribadi, dan individu yang melakukan perubahan ${ }^{4}$.

Model rekonstruksi sosial berorientasi pada terciptanya sikap kritis. Siswa diharapkan tidak hanya sekedar menerima apa yang diusung oleh guru, dan guru pun harus siap dengan serangkaian strategi untuk mengajak anak berpikir kritis. Pada dasarnya model rekonstruksi

${ }^{4}$ Hasil observasi pada tanggal 29 Nopember 2019 
sosial merupakan sebuah pembelajaran yang berpusat pada siswa dan memiliki tujuan untuk memahami dan menghadapi isu-isu atau masalah-masalah sosial yang terjadi di masyarakat, serta menjadikan siswa sebagai aktor dalam perubahan dan perbaikan kondisi sosial menuju yang lebih baik. Guru dalam pembelajaran model ini adalah sebagai pemandu selama proses pembelajaran yang mendorong siswa untuk belajar secara kritis, dalam aspek budaya dan kehidupan sosial siswa.

Implementasi kurikulum rekonstruksi sosial di pesantren ini ialah memformulasi Integrated homework diantaranya; (1) Menerapkan kemampuan guru dan santri dalam menghubungkan satu masalah dengan masalah lainnya, (2) Memaksimalkan ruang waktu pembelajaran, (3) Menghasilkan produk, (4) Tugas bisa bersifat individual dan kolektif, dan (5) Meminimalisir beban pembelajaran

Model rekonstruksi sosial Vygotsky menempatkan siswa pada zona terdekat perkembangan anak atau sering disebut zone proximal development (ZPD). Vygotsky dalam teorinya ini berusaha mengajak siswa untuk belajar pada posisinya yang tepat sesuai dengan tingkat perkembangan anak, dan menuntun siswa pada awal tahap pembelajarannya yang kemudian mengurangi tuntunannya ketika siswa sudah mulai mampu mengambil tanggung jawab belajarnya, tahapan ini sering disebut dengan scaffolding.

Menurut Vygotsky scaffolding merupakan bentuk bantuan yang tepat waktu yang juga harus ditarik tepat waktu ketika interaksi belajar sedang terjadi. Scaffolding atau pemberian bantuan yang diberikan kepada siswa dapat berupa gambar, petunjuk, dorongan, peringatan, menguraikan masalah-masalah kedalam langkah-langkah pemecahan, memberikan contoh, dan tindakan lain yang memungkinkan siswa itu belajar mandiri. Pemberian bantuan ini bertujuan agar siswa mampu menyelesaikan masalah-masalah yang diberikan secara mandiri. Pemberian bantuan dalam teknik scaffolding ini dapat berupa kelompok maupun individual.

c. Evaluasi kurikulum dalam perspektif kurikulum rekonstruksi sosial

Evaluasi yang dilakukan adalah model objektif, pesantren memilki konsep integratif homework sebuah pola evaluasi menggabungkan mata pelajaran yang di emban oleh para santri prinsifnya mengkaitkan beberapa tema pelajaran menjadi satu evaluasi. Tujuannya adalah memberikan pola evaluasi yang sederhana dan komprehensif bagi santri. Nilai yang diberikan berupa kuantitatif tapi prosesnya kualitatif, nilai kejujuran yang kami berikan kebada mereka ${ }^{5}$.

Evaluasi kurikulum di Pesantren Persatuan Islam No. 110 Manba'ul Huda Bandung dalam perspektif kurikulum rekonstruksi sosial,

\footnotetext{
${ }^{5}$ Hasil wawancara dengan ustadz Agus (waka Kurikulum) pada tanggal 29 Nopember 2019
} 
Curriculum analysis of Persis 110 Bandung in the curriculum perspective curriculum reconstruction social

dilakukan dengan evaluasi melalui tiga prinsip utama yakni; Evaluasi dilaksanakan secara terus menerus (continue), Evaluasi menyeluruh (Comprehensive) dan Evaluasi obyektif (Obyective)

Dalam kegiatan evaluasi para siswa juga dilibatkan, keterlibatan mereka terutama dalam memilih, menyusun, dan menilai bahan yang akan diujikan. Soal-soal yang akan diujikan dinilai lebih dulu baik ketepatan maupun keluasan isinya, juga keampuhan menilai pencapaian tujuan-tujuan pembangunan masyarakat yang sifatnya kualitatif. (R. Pranata, 2013) Evaluasi tidak hanya menilai apa yang telah dikuasai siswa, tetapi juga menilai pengaruh kegiatan sekolah terhadap masyarakat. Pengaruh tersebut terutama menyangkut perkembangan masyarakat dan peningkatan taraf kehidupan masyarakat. (Lasmawan, 2010, p. 93)

\section{SIMPULAN}

Perencanaan kurikulum di Pesantren Persatuan Islam No. 110 Manba'ul Huda dalam perspektif kurikulum rekonstruksi sosial masih belum melakukan student need dan student inters, masih menggunakan feeling matter atau Non Planing Model (Model Tanpa perencanaan) lebih jauh lagi mengadakan survey Need user dalam pandangan. kurikulum rekonstruksi Sosial, dalam proses perencanaan kurikulum mestinya sekolah melakaukan analisis kebutuhan siswa atau secara mendetail dan berpandangan Futuristik model rekonstruksi sosial Vigotsky.

Implementasi kurikulum di Pesantren Persatuan Islam No. 110 Manba'ul Huda Bandung dalam perspektif Kurikulum Rekonstruksi Sosial memformulasi Integrated homework diantaranya; (1) Menerapkan kemampuan guru dan santri dalam menghubungkan satu masalah dengan masalah lainnya, (2) Memaksimalkan ruang waktu pembelajaran, (3) Menghasilkan produk, (4) Tugas bisa bersifat individual dan kolektif, dan (5) Meminimalisir beban pembelajaran

Evaluasi kurikulum di Pesantren Persatuan Islam No. 110 Manba'ul Huda Bandung dalam perspektif kurikulum rekonstruksi sosial, dilakukan dengan evaluasi melalui tiga prinsip utama yakni; Evaluasi dilaksanakan secara terus menerus (continue), Evaluasi menyeluruh (Comprehensive) dan Evaluasi obyektif (Obyective) serta metode yang dilakukan secara umum dapat di klasifikasikan dengan evaluasi secara formal maupun non formal yang bertujuan evaluasi untuk proses perbaikan yang nantinya meminimalisir kesalahan yang terjadi. 


\section{REFERENSI}

Aly, A. (2011). Pendidikan Islam Multikultural di Pesantren. Yogyakarta: Pustaka Pelajar.

Arifin, M. (1995). Kapita Selekta Pendidikan Islam. Jakarta: Bumi Aksara.

Arifin, Z. (2012). Konsep dan Model Pengembangan Kurikulum. Bandung: Remaja Rosdakarya.

Bawani, I. (1993). Tradisionalisme Dalam Pendidikan Islam. Surabaya: Al-Ikhlas.

Beauchamp, G. A. (1975). Curriculum Theory: Third Edition. Willmette, . Illinois: The Kagg Press.

Creswell, J. (2015). Research Desaign, Quantitative, Qualitative and Mixed Approachs, Fourth Edition. SAGE Publication, Inc. Diterjemahkan oleh Achmad Fawaid dan Riaayati Kusmini Pancasari. Bandung: Pustaka Pelajar.

Depdiknas. (2003). Undang-undang RI No 20 Tahun 2003 Tentang Sistem Pendidikan Nasional. Jakarta: Depdiknas.

Efendy, B. (1986). Nilai-nilai Kaum Santri dalam Dawan Raharjo (ed), Pergulatan Dunia pesantren Membangun dari Bawah. Jakarta: LP3M.

Endin, M. (2005). Pesantren Kilat Alternatif Pendidikan Agama di Luar Sekolah. Jakarta: Pustaka Al-Kautsar.

Hamalik, O. (2008). Kurikulum dan Pembelajaran. Jakarta: Bumi.

Hamalik, Oemar. (2007). Dasar - dasar Pengembangan Kurikulum. Bandung: Rosda Karya.

Hardiman, F. B. (2009). Demokrasi Liberalatif Menimbang 'Negara Hukum' dan 'Ruang Publik' dalam Teori Diskursus Jurgen Habernas. Yogyakarta: KANISIUS (Anggota IKAPI).

Lasmawan, W. (2010). Menelisik Pendidikan IPS Perspektif Konstektual-Empiris. Singaraja: Mediakom Indonesia Press Bali.

Mastuhu. (1994). Dinamika Pendidikan Pesantren: Suatu Kajian tentang Unsur dan Nilai Sistem Pendidikan Pesantren. Jakarta: INIS.

McNeil, J. D. (1996). Contemporary Curriculum . United State of Amerika: Wiley Joddey-Bass Education.

Mochtar, A. (1999). Pesantren Masa Depan Wacana Pemberdayaan dan Transformasi Pesantren . Bandung: Pustaka Hidayah.

Oliva, P. F. (2013). Developing the Curriculum: Eighth Edition. New Jersey: Pearson Education Inc.

R. Pranata, L. (2013). Pengaruh implementasi model rekonstruksi sosial Vigotsky dengan teknik Scaffolding terhadap sikap sosial dan prestasi belajar IPS. $e$ Journal Program Pascasarjana Universitas Pendidikan Ganesha Program Studi Pendidikan Dasar (Volume 3 Tahun 2013) .

RI., D. A. (2003). Silabus Pesantren. Jakarta.

Rusman. (2009). Manejemen Kurikulum. Jakarta: Grafindo Persada.

Steenbrink, K. A. (1991). Pesantren, Madrasah, Sekolah: Pendidikan Islam dalam Kurun Moderen. Jakarta:: LP3ES.

Sukmadinata, N. S. (2014). Pengembangan Kurikulum. Bandung: PT Remaja Rosdakarya. 
Curriculum analysis of Persis 110 Bandung in the curriculum perspective curriculum reconstruction social

Taba, H. (1962). Curriculum Development. New York: Harcourt, Brace \& World.Inc.

Wahid, A. (2001). Menggerakkan Tradisi Esai-esai Pesantren. Yogyakarta: LKIS.

Zais, R. S. (1976). Curriculum Principles and Foundations. New York: Happer \& Row Publishers Inc. 